\title{
MODELLING OF THE ENERGY SUPPLY EQUIPMENT OF THE AIR BRAKING SYSTEM OF A FARM TRACTOR
}

\author{
ZBIGNIEW KAMIŃSKI'
}

\section{Summary}

Farm tractors are provided with pneumatic systems to control and operate air braking systems as well as pneumatic suspension systems, the latter being increasingly often applied to high-capacity trailers. The excessive consumption of compressed air may adversely affect the braking effectiveness of a tractor-trailer unit; therefore, the impact of performance of the air supply equipment of the tractor on the transient processes taking place in the air braking system of the trailer should be taken into consideration as early as at the design stage.

A mathematical model of the air supply equipment, consisting of functional and structural models of individual equipment components such as compressor, pressure regulator, and compressed air reservoir, has been presented in this paper. An example has been included, where the computer model of the supply system, prepared in the Matlab-Simulink program, was used to assess the correctness of compressor selection to the pneumatic system of the Pronar 5110 tractor. The adequacy of the implemented computer model of the air supply equipment, experimentally confirmed, was evaluated with statistical methods, with the use of the Kolmogorov-Smirnov test.

The computer model developed may be used as a tool to assess the correctness of selection of parameters of the air supply equipment within the designing process and as a subsystem in order to evaluate, with the use of simulation methods, the transient processes taking place in the air braking systems of agricultural vehicles.

Keywords: farm tractor, pneumatics, braking system, air supply equipment, modelling

\section{Introduction}

In most farm tractors, hydraulic systems are used to actuate their braking mechanisms; sometimes, mechanical or pneumatic systems are used as an alternative for this purpose. The pneumatic systems installed in tractors are chiefly used to supply energy to, and to control, air braking systems of trailers and farm machinery coupled with the tractors.

'Bialystok University of Technology, Chair of Machine Building and Operation, Wiejska 45C Street, 15-351 Białystok, z.kaminski@pb.edu.pl 
A typical pneumatic system of a farm tractor consists of two major parts: air supply system and control system. The role of the control system is to provide follow-up control of a singleline or two-line braking system of the trailer in a way that should enable synchronous braking of both the vehicles. The functions of the air supply system are to compress and purify air and to keep adequate air pressure in the tractor and trailer reservoirs so that the required trailer braking effectiveness is ensured. The pneumatic system is also used to supply compressed air to suspension systems of high-capacity agricultural trailers. In such conditions of operation of the pneumatic system, considerable quantities of compressed air are consumed, which may adversely affect the effectiveness of braking of the tractortrailer unit. To select appropriate system design parameters and to analyse the operation of the pneumatic system of the tractor in transient states with the use of simulation methods, the preparation of a mathematical model of individual system components, including the air supply equipment, was found necessary.

\section{Mathematical model}

A simplified schematic diagram of a two-line pneumatic system of a farm tractor has been presented in Fig. 1. The air supply equipment includes compressor 1, pressure regulator 2 , compressed air reservoir 4, and supply line 5 with a coupling to supply compressed air to the braking system of the trailer. Compressed air is also fed to a control system, which includes valve 6 to control trailer brakes, and control line 7. The air supply equipment may also include other components, not shown in the drawing, such as filter, oil separator, safety valve, or pressure reducing valve indispensable in high-pressure systems.

When the maximum value of the regulated pressure $\mathrm{p}_{\max }$ in the reservoir is achieved, abrupt operation of the pressure regulator takes place, in result of which the delivery port of the compressor is connected to a vent. When this connection is open, the compressor operates without load and it is gradually cooled. When the pressure in the reservoir drops to the lowest acceptable level $\mathrm{p}_{\min }$ the regulator abruptly reconnects the compressor

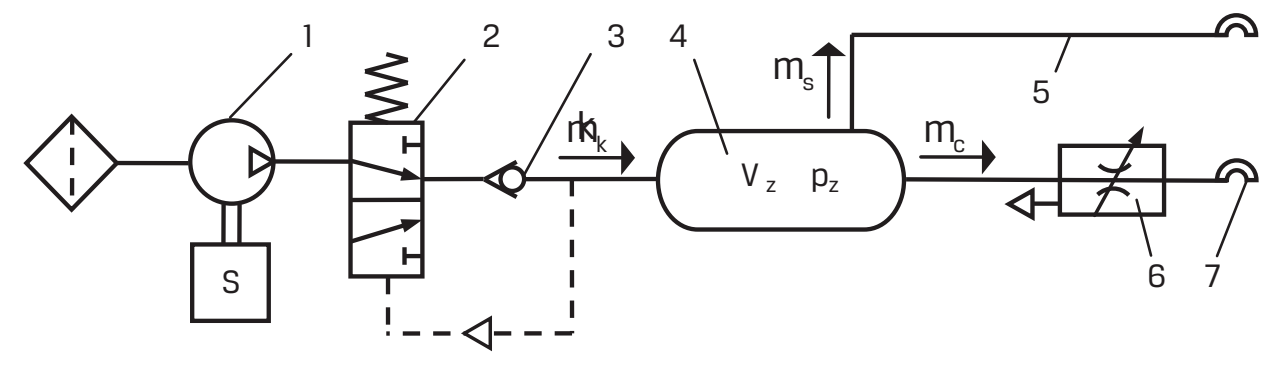

Fig. 1. Computational diagram of the pneumatic system of a farm tractor: 1 - compressor; 2 - pressure regulator; 3 - check valve; 4 - air reservoir; 5 - supply line; 6 - trailer brake control valve; 7 - control line. 
with the reservoir. This type of operation of the regulator can be described by a static characteristic curve representing the operation of a bistable relay with a hysteresis loop of width equal to $\mathrm{p}_{\max }-\mathrm{p}_{\min }$.

Assuming, to simplify, that the pressure in the compression pressure of the compressor is equal to that in the reservoir, i.e. $\mathrm{p}_{\mathrm{z}}$ (short length and small cubic capacity of the parts connecting the compressor with the reservoir), we may describe the volume flow of the air delivered by the compressor as follows [4]:

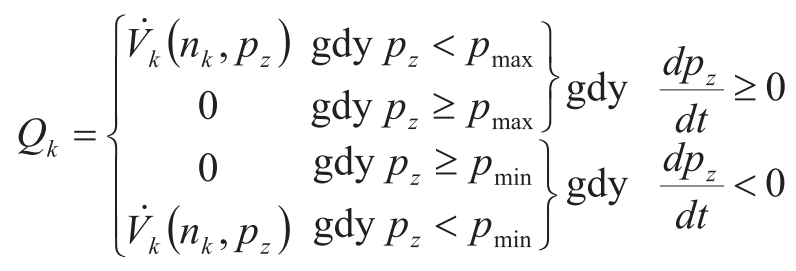

The volume flow $\dot{V}_{k}\left(n_{k}, p_{z}\right)$ depends on compressor shaft speed $\mathrm{n}_{\mathrm{k}}$ and pressure $\mathrm{p}_{\mathrm{z}}$ in the reservoir:

$$
\dot{V}_{k}\left(n_{k}, p_{z}\right)=\eta_{v} \cdot V_{s} \cdot i_{c} \frac{n_{k}}{60}=\eta_{v} \frac{\pi \cdot D_{c}^{2}}{4 \cdot 60} \cdot S \cdot i_{c} \cdot n_{k} \quad\left[\mathrm{~m}^{3} / \mathrm{s}\right]
$$

where: $\eta_{v}$ - volumetric efficiency; $V_{s}$ - displacement volume $\left[m^{3}\right], D_{c}$ - cylinder diameter [m], S - piston stroke [m], $\mathrm{i}_{\mathrm{c}}$ - number of cylinders.

The mass flow of the air delivered by the compressor may be calculated by multiplying the volume flow by air density in ambient conditions:

$$
\dot{m}_{k}=\rho_{a} \cdot Q_{k}=\frac{p_{a}}{R T_{a}} Q_{k} \quad[\mathrm{~kg} / \mathrm{s}],
$$

where: $\mathrm{p}_{\mathrm{a}}$ - atmospheric pressure $[\mathrm{Pa}], \mathrm{T}_{\mathrm{a}}$ - ambient temperature $[\mathrm{K}], \mathrm{R}$ - gas constant $[\mathrm{J} /(\mathrm{kgK})]$.

The value of volumetric efficiency $\eta v$ may be estimated from a theoretical dependence [1], assuming the inlet pressure as being equal to the atmospheric pressure:

$$
\eta_{v}=1-\frac{V_{s z}}{V_{s}}\left[\left(\frac{p_{z}}{p_{a}}\right)^{1 / n}-1\right],
$$

where: $\mathrm{V}_{\mathrm{sz}}$ - clearance volume $\left[\mathrm{m}^{3}\right], \mathrm{n}$ - polytropic exponent, $\mathrm{n}=1,25 \div 1,4$. 
The volumetric efficiency $\eta_{\mathrm{v}}$ may also be determined by the non-linear regression method, based on the compressor delivery performance curve. In general, this coefficient depends on compressor shaft speed $n_{k}$ and delivery pressure (pressure $p_{z}$ in the reservoir). According to author's research work, the volumetric efficiency may be described for most piston compressors by a non-linear regression equation in the following form:

$$
\eta_{v}=A_{1}+A_{2} n_{k}+A_{3} n_{k}^{2}+A_{4} p_{z}+A_{5} p_{z}^{2},
$$

where: $\mathrm{n}_{\mathrm{k}}$ - compressor shaft speed [rev/min], $\mathrm{p}_{\mathrm{z}}$ - delivery pressure $[\mathrm{kPa}], \mathrm{A}_{1} \div \mathrm{A}_{5}$ - coefficients of regression. For the FOS Polmo compressor model 601.23.931 installed in the Pronar 5110 tractor: $A_{1}=0,80698 ; A_{2}=0,46902 E-4 ; A_{3}=-1,47791 E-8 ; A_{4}=-7,81944 E-4$; $A_{5}=3,80523 E-7\left(R^{2}=99,37 \%\right)$.

The compressor shaft speed may be calculated from the tractor speed. Knowing the total gear ratio of the tractor power transmission system, we may calculate the engine speed and then the compressor shaft speed:

$$
n_{k}(t)=\frac{30 \cdot i_{c} v}{\pi \cdot i_{k} r_{k}(1-s)}[\mathrm{revs} / \mathrm{min}]
$$

where: $\mathrm{v}$ - tractor speed $[\mathrm{m} / \mathrm{s}], \mathrm{i}_{\mathrm{c}}$ - total gear ratio of the tractor power transmission system, $\mathrm{i}_{\mathrm{k}}$ - gear ratio of the compressor drive system, $\mathrm{r}_{\mathrm{k}}$ - kinematic radius of the tractor wheel [m], s - slip of the driving wheels.

During the braking process, the compressor shaft speed drops from the level corresponding to the engine speed at the beginning of the braking process to that at the engine idling speed:

$$
n_{k}(t)=n_{k h}-a_{1} \cdot t \text { dla } n_{k}>n_{k j},
$$

where: $\mathrm{n}_{\mathrm{kh}}$ - compressor shaft speed corresponding to the tractor speed at the beginning of the braking process [revs/min]; $\mathrm{a}_{1}$ - ratio of the compressor shaft speed (engine speed) drop during the braking process, determined experimentally [revs/(min $\times s)$; $\mathrm{n}_{\mathrm{kj}}$ - compressor shaft speed at the engine idling speed [revs/min].

The equation of balance of the mass flows in the reservoir has the form:

$$
\frac{d m_{z}}{d t}=\dot{m}_{k}-\dot{m}_{s}-\dot{m}_{c},
$$

where: $\dot{m}_{s}$ - mass flow entering the supply line $[\mathrm{kg} / \mathrm{s}], \dot{m}_{c}$ - mass flow entering the control line $[\mathrm{kg} / \mathrm{s}]$.

Based on the energy conservation law for an open system and the ideal gas equation of state, we obtain the following dependencies describing the changes of temperature and pressure of air in the reservoir [3]: 


$$
\begin{aligned}
& \frac{d p_{z}}{d t}=\frac{1}{V_{z}}\left[(\kappa-1)\left(\dot{Q}+\dot{H}_{k}-\dot{H}_{s}-\dot{H}_{c}\right)\right] \\
& \dot{Q}=\alpha_{z} A_{z}\left(T_{w}-T_{z}\right) \quad \dot{H}_{i}=\dot{m}_{i} c_{p} T_{i} \\
& \frac{d T_{z}}{d t}=\frac{T_{z}}{p_{z} V_{z}}\left[V_{z} \frac{d p_{z}}{d t}-R T_{z}\left(\dot{m}_{k}-\dot{m}_{s}-\dot{m}_{c}\right)\right]
\end{aligned}
$$

where: $\mathrm{H}_{\mathrm{k}}$ - enthalpy of the flow generated by the compressor [J], $\mathrm{H}_{\mathrm{s}}$ - enthalpy of the flow entering the supply line [J], $\mathrm{H}_{\mathrm{c}}$ - enthalpy of the flow entering the control line [J], $\mathrm{Q}$ - heat exchanged with the environment $[\mathrm{J}], \alpha_{\mathrm{z}}$ - heat transfer coefficient $\left[\mathrm{W} / \mathrm{m}^{2} \mathrm{~K}\right], \mathrm{T}_{\mathrm{z}}$ - temperature of air in the reservoir $[\mathrm{K}], \mathrm{A}_{\mathrm{z}}$ - heat transfer area, $\mathrm{T}_{\mathrm{w}}$ - temperature of reservoir walls [K].

The temperature of the airflow generated by the compressor may be estimated from the polytropic equation:

$$
T_{k}=T_{a}\left(\frac{p_{z}}{p_{a}}\right)^{\frac{n-1}{n}}
$$

\section{Example of a model application}

The mathematic model of the air supply system was employed to build, in the MatlabSimulink program, a computer model of the pneumatic system of the Pronar 5110 tractor. The brake control system of this tractor includes a hydraulically operated Haldex brake control valve model 329020 201. The computer model presented in Fig. 2, in a version intended for the simulation of functioning of the supply system, was used to check the compressor delivery rate at filling a dummy reservoir of $60 \mathrm{dm}^{3}$ capacity (imitating the trailer braking system) connected to the supply coupling. A test of this type is also normally carried out during validation tests of farm tractors [2].

To assess the simulation curves obtained, experimental curves recorded during tests of the pneumatic system of the tractor were introduced into the computer model in the form of the "From File" component (coloured).

A set of results of the simulation tests, obtained in the form of time histories of the air pressure $\mathrm{p}_{\mathrm{v}}$ and temperature $\mathrm{T}_{\mathrm{v}}$ in the dummy reservoir and of the volumetric delivery rate $\mathrm{Q}_{\mathrm{k}}$ of the compressor have been presented as an example in Fig. 3. In equation (11), from which the temperature of the airflow generated by the compressor was calculated, the polytropic exponent was assumed as $n=1,26$. A $p_{\text {ve }}$ pressure time history obtained from experiments has also been plotted on the graph. The time histories, obtained from the simulation and experimental tests, were used to validate the computer model. Results of the KolmogorovSmirnov non-parametric test calculated in the Matlab program for a significance level of 


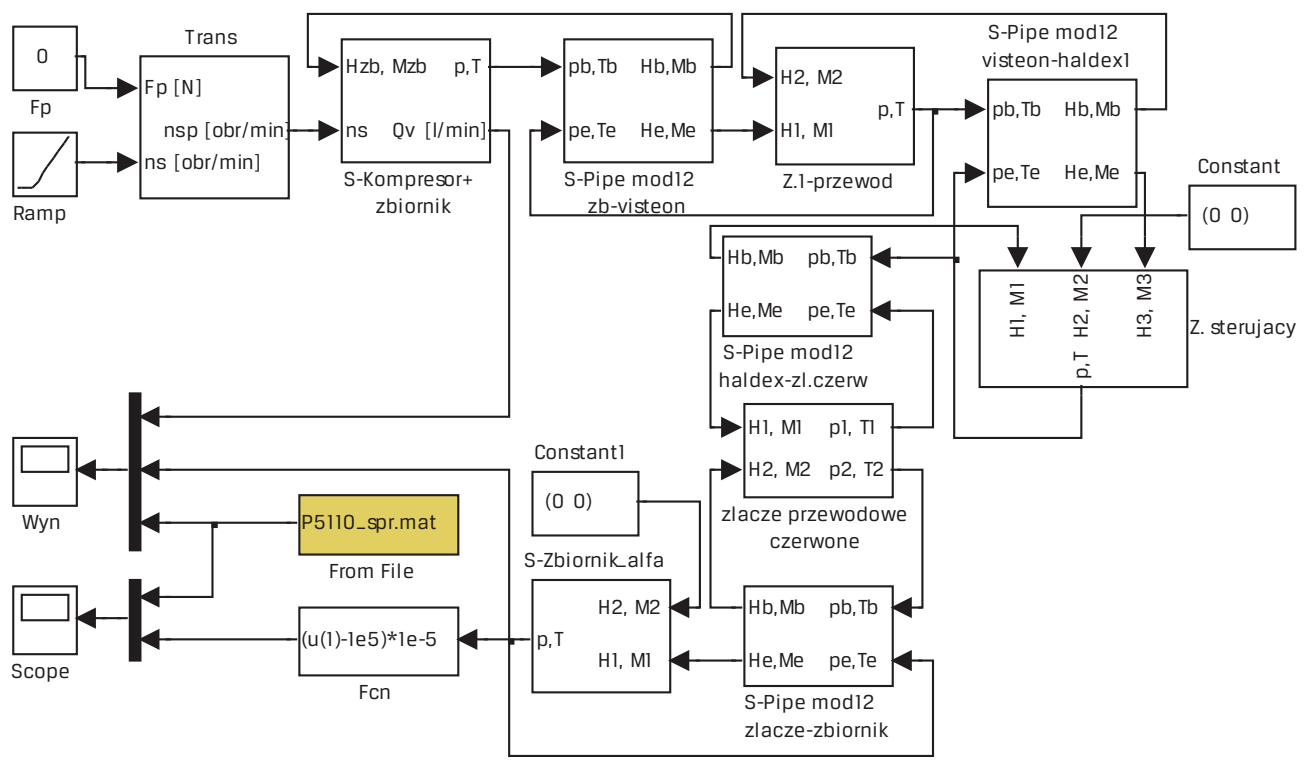

Fig. 2. Block diagram of the pneumatic system of the Pronar 5110 tractor, used for the simulation of functioning of the air supply system (compressor model 601.23.931 manufactured by Polmo Praszka).

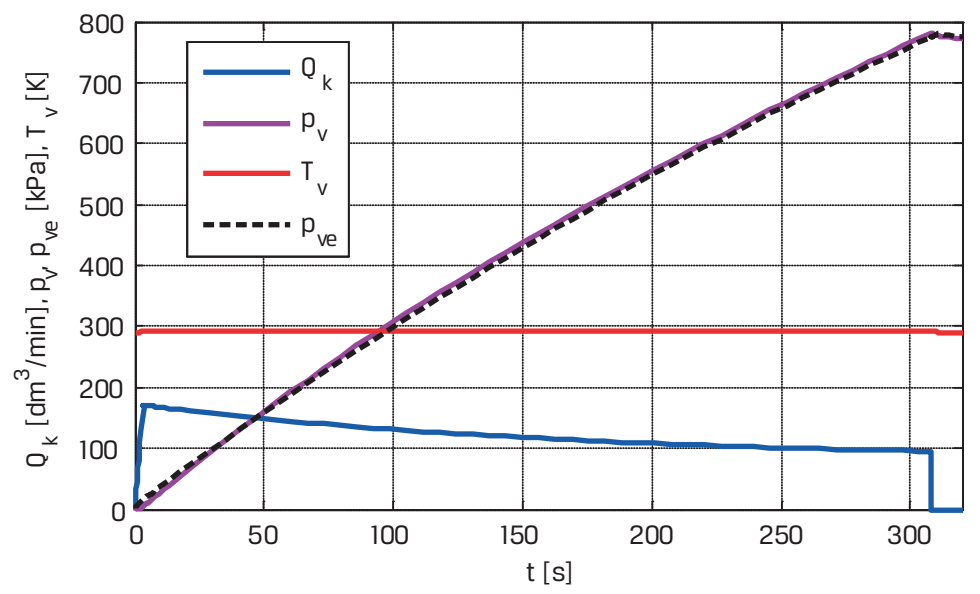

Fig. 3. Results of a simulation test of operation of the air supply part of the pneumatic system of the Pronar 5110 tractor, carried out to check the compressor delivery rate: $Q_{k}$ - volumetric delivery rate, $\mathbf{p}_{\mathbf{v}}, \mathbf{T}_{\mathrm{v}}$ - pressure and temperature, $\mathbf{p}_{\mathrm{ve}}$ - pressure obtained from experiments. 
0.05 (ks2 $=0.0198<0.1923$ for 101 points) and the value of the determination index $\mathrm{R} 2=0.999$ confirmed the adequacy of the computer model.

Based on the curves obtained for the model, the time of achieving a minimum acceptable pressure of 6.5 bar in the dummy air reservoir was determined. This time value differed by $2.1 \mathrm{~s}$ from the time measured during experiments $(245.6 \mathrm{~s})$, which again confirmed the accuracy of the computer model to be satisfactory from the point of view of the modelling purpose.

\section{Conclusions}

The mathematical model of the air supply system as developed within this study may be used for the construction of a computer model of the pneumatic system of farm tractors and utility vehicles in order to forecast, by simulation methods, the system performance characteristics at the early design stage. The adequacy of the computer model of the air supply system, built in the Matlab-Simulink program, was confirmed by results of the Kolmogorov-Smirnov test where a comparison was made between the experimental and simulation time histories of the system pressure, obtained when verifying the correctness of selection of delivery rate of the compressor to be installed in the Pronar 5110 farm tractor.

\section{References}

[1] BLOCH, H.,P.: A Practical Guide to Compressor Technology. John Wiley \& Sons, Hoboken, New Jersey, 2006.

[2] KAMIŃSKI Z., CZABAN J.: Propozycja programu badań układów hamulcowych ciągników rolniczych (Proposal of a program of testing braking systems of farm tractors). MOTROL - Motoryzacja i energetyka rolnictwa (MOTROL - Motorization and power industry in agriculture), Vol. 8 (edited by Eugeniusz Krasowski), Polish Academy of Sciences, Division in Lublin, Commission of Motorization and Power Industry in Agriculture, 2006, pp. 92-100.

[3] KAMIŃSKI Z., KULESZA Z., MIATLUK K., MIATLUK M: Dynamika pneumatycznych układów napędowych (Dynamics of pneumatic driving systems), edited by F. Siemieniako. Rozprawy naukowe No. 145. Wydawnictwo Politechniki Białostockiej, Białystok 2007.

[4] MIATLUK M., AVTUŠKO V.: Dinamika pnevmatičeskich i gidravličeskich privodov avtomobilej. Mašinostroenije, Moskva 1980. 


\title{
MODELOWANIE ZESPOLU ZASILAJĄCEGO INSTALACJI PNEUMATYCZNEJ CIĄGNIKA ROLNICZEGO
}

\author{
ZBIGNIEW KAMIŃSKI
}

\section{Streszczenie}

Ciągniki rolnicze są wyposażone w instalacje pneumatyczne do sterowania i napędu pneumatycznych układów hamulcowych a także pneumatycznych układów zawieszenia, coraz częściej stosowanych w przyczepach o dużej ładowności. Zwiększone zużycie sprężonego powietrza może wpływać ujemnie na efektywność hamowania zespołu ciągnik-przyczepa, dlatego już na etapie projektowania należy uwzględnić wpływ pracy zespołu zasilającego instalacji ciągnika na przebieg procesów przejściowych w pneumatycznym układzie hamulcowym przyczepy. W niniejszej pracy przedstawiono model matematyczny zespołu zasilającego, składający się z modeli funkcjonalno-strukturalnych poszczególnych podzespołów, w tym: sprężarki, regulatora i zbiornika sprężonego powietrza. Zamieszczono przykład wykorzystania opracowanego w programie Matlab-Simulink modelu komputerowego zespołu zasilającego do oceny poprawności doboru sprężarki w instalacji pneumatycznej ciągnika Pronar 5110. Potwierdzoną doświadczalnie adekwatność zrealizowanego modelu komputerowego zespołu zasilającego oceniono metodami statystycznymi przy użyciu testu Kołmogorowa-Smirnowa. Opracowany model komputerowy może być wykorzystany jako narzędzie do oceny poprawności doboru parametrów zespołu zasilającego w procesie projektowania oraz jako podsystem do analizy metodami symulacyjnymi procesów przejściowych w pneumatycznych układach hamulcowych pojazdów rolniczych.

Słowa kluczowe: ciągnik rolniczy, pneumatyka, układ hamulcowy, zespół zasilający, modelowanie

\section{Wprowadzenie}

W większości ciągników rolniczych do uruchamiania ich mechanizmów hamujących wykorzystuje się układy hydrauliczne, rzadziej mechaniczne czy pneumatyczne. Natomiast montowane w ciągnikach instalacje pneumatyczne służą przede wszystkim do zasilania i sterowania pneumatycznych układów hamulcowych przyczep i maszyn rolniczych agregatowanych z ciągnikami.

Typowa kombinowana instalacja pneumatyczna ciągników rolniczych składa się z dwóch zespołów: zespołu zasilającego i zespołu sterującego. Zadaniem zespołu sterującego

Politechnika Białostocka, Wydział Mechaniczny, Katedra Budowy i Eksploatacji Maszyn, ul. Wiejska 45a, 15 - 351 Białystok, z.kaminski@pb.edu.pl 
jest sterowanie nadążne jedno- lub dwuprzewodowym układem przyczepy w sposób umożliwiający synchronię hamowania obu pojazdów. Zadaniem zespołu zasilającego jest sprężenie i oczyszczenie powietrza oraz utrzymanie odpowiedniego ciśnienia powietrza w zbiornikach ciągnika i przyczepy w celu zapewnienia wymaganej skuteczności hamowania przyczepy. Instalację pneumatyczną wykorzystuje się również do zasilania w sprężone powietrze pneumatycznych układów zawieszenia przyczep rolniczych o dużej ładowności. W takich warunkach pracy instalacji pneumatycznej występuje znaczne zużycie sprężonego powietrza, co w przypadku powtarzających się cyklicznie hamowań może wpływać ujemnie na efektywność hamowania zespołu pojazdów ciągnik-przyczepa. W celu doboru parametrów konstrukcyjnych, a także analizy pracy instalacji pneumatycznej ciągnika w stanach nieustalonych przy użyciu metod symulacyjnych, niezbędne jest opracowanie modelu matematycznego poszczególnych zespołów instalacji, w tym również zespołu zasilającego.

\section{Model matematyczny}

Uproszczony schemat dwuprzewodowej instalacji pneumatycznej ciągnika rolniczego przedstawiono na rys.1. W skład zespołu zasilającego wchodzi sprężarka 1, regulator ciśnienia 2, zbiornik sprężonego powietrza 4 i przewód 5 ze złączem do zasilania układu hamulcowego przyczepy. Sprężone powietrze jest podawane również do zespołu sterującego, który zawiera zawór 6 sterujący hamulcami przyczepy i przewód sterujący 7 . W zespole zasilającym mogą być również inne elementy, niepokazane na schemacie, takie jak: filtr, odolejacz, zawór bezpieczeństwa, czy niezbędny w instalacjach wysokociśnieniowych zawór redukcyjny.

Po osiągnięciu maksymalnej wartości ciśnienia regulowanego $\mathrm{p}_{\max } \mathrm{w}$ zbiorniku, następuje skokowe zadziałanie regulatora ciśnienia, który łączy kanał tłoczny sprężarki z wylotem do atmosfery. W tym czasie sprężarka pracuje bez obciążenia i stopniowo się chłodzi. Z chwilą, gdy ciśnienie w zbiorniku spadnie do najniższej dopuszczalnej wartości $\mathrm{p}_{\min }$ regulator

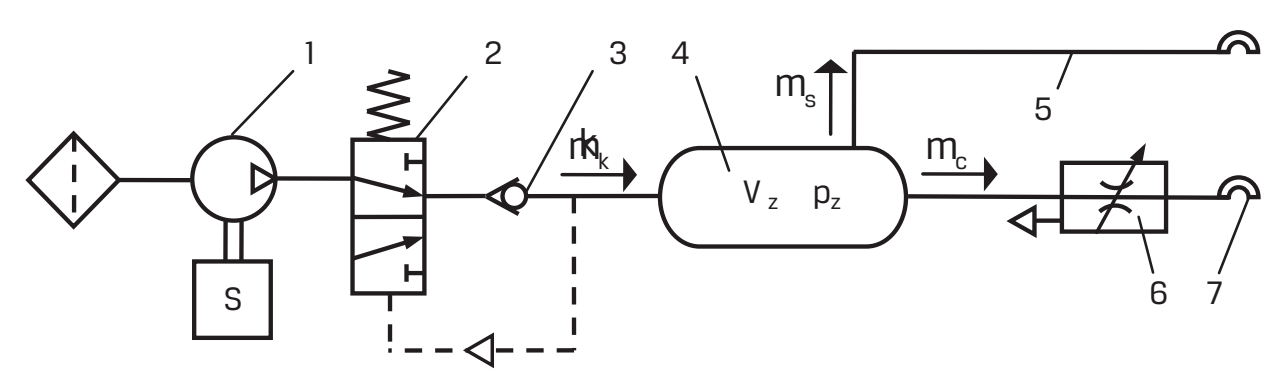

Rys.1. Schemat obliczeniowy instalacji pneumatycznej ciągnika rolniczego: 1 - sprężarka, 2 - regulator, 3 - zawór zwrotny, 4 - zbiornik powietrza, 5 - przewód zasilający, 6 - zawór sterujący hamulcami przyczepy, 7 -przewód sterujący. 
ponownie skokowo łączy sprężarkę ze zbiornikiem. Takie działanie regulatora daje się opisać charakterystyką statyczną przekaźnika dwustanowego z pętlą histerezy o szerokości $\mathrm{p}_{\max }-\mathrm{p}_{\min }$.

Zakładając w uproszczeniu, że ciśnienie w komorze sprężania kompresora jest równe ciśnieniu w zbiorniku $\mathrm{p}_{\mathrm{z}}$ (mała długość, mała objętość elementów łączących sprężarkę ze zbiornikiem) można strumień objętościowy powietrza podawanego ze sprężarki zapisać następująco [4]:

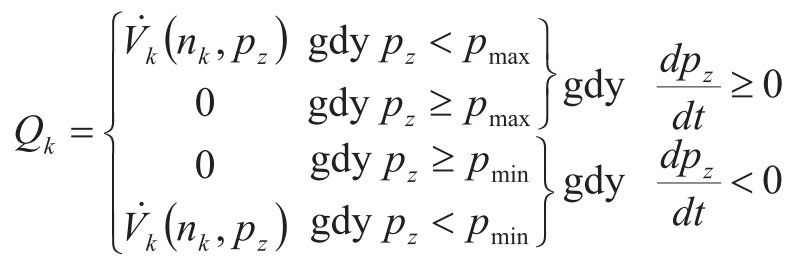

Strumień objętościowy $\dot{V}_{k}\left(n_{k}, p_{z}\right)$ zależy od prędkości obrotowej $\mathrm{n}_{\mathrm{k}}$ wału sprężarki i ciśnienia $\mathrm{p}_{\mathrm{z}} \mathrm{w}$ zbiorniku:

$$
\dot{V}_{k}\left(n_{k}, p_{z}\right)=\eta_{v} \cdot V_{s} \cdot i_{c} \frac{n_{k}}{60}=\eta_{v} \frac{\pi \cdot D_{c}^{2}}{4 \cdot 60} \cdot S \cdot i_{c} \cdot n_{k} \quad\left[\mathrm{~m}^{3} / \mathrm{s}\right]
$$

gdzie: $\eta_{\mathrm{v}}$ - współczynnik napełnienia cylindra, $\mathrm{V}_{\mathrm{s}}$ - objętość skokowa $\left[\mathrm{m}^{3}\right], \mathrm{D}_{\mathrm{c}}$ - średnica cylindra [m], S - skok tłoka [m], i - liczba cylindrów.

Masowy strumień powietrza tłoczonego ze sprężarki wylicza się mnożąc strumień objętościowy przez gęstość powietrza w warunkach otoczenia:

$$
\dot{m}_{k}=\rho_{a} \cdot Q_{k}=\frac{p_{a}}{R T_{a}} Q_{k} \quad[\mathrm{~kg} / \mathrm{s}]
$$

gdzie: $\mathrm{p}_{\mathrm{a}}$ - ciśnienie atmosferyczne $[\mathrm{Pa}], \mathrm{T}_{\mathrm{a}}$ - temperatura otoczenia [K], $\mathrm{R}$ - stała gazowa $[\mathrm{J} /(\mathrm{kgK})]$.

Wartość współczynnika napełnienia (sprawność wolumetryczną) ๆv można oszacować z zależności teoretycznej [1], przyjmując ciśnienie ssania równe ciśnieniu atmosferycznemu:

$$
\eta_{v}=1-\frac{V_{s z}}{V_{s}}\left[\left(\frac{p_{z}}{p_{a}}\right)^{1 / n}-1\right]
$$

gdzie: $\mathrm{V}_{\mathrm{sz}}$ - objętość przestrzeni „szkodliwej" [m³], $\mathrm{n}$ - wykładnik politropy, $\mathrm{n}=1,25 \div 1,4$.

Współczynnik napełnienia $\eta_{v}$ można również wyznaczyć metodą regresji nieliniowej na podstawie charakterystyki wydajnościowej sprężarki. W ogólnym przypadku współczynnik 
ten zależy od prędkości obrotowej $\mathrm{n}_{\mathrm{k}}$ i ciśnienia tłoczenia (ciśnienia $\mathrm{p}_{\mathrm{z}} \mathrm{w}$ zbiorniku). Z badań autora wynika, że dla większości sprężarek tłokowych współczynnik napełnienia można opisać równaniem regresji nieliniowej w postaci:

$$
\eta_{v}=A_{1}+A_{2} n_{k}+A_{3} n_{k}^{2}+A_{4} p_{z}+A_{5} p_{z}^{2}
$$

gdzie: $\mathrm{n}_{\mathrm{k}}$ - prędkość obrotowa wału sprężarki [obr/min], $\mathrm{p}_{\mathrm{z}}$ - ciśnienie tłoczenia [kPa], $\mathrm{A}_{1} \div \mathrm{A}_{5}$ - współczynniki regresji; dla sprężarki FOS Polmo 601.23.931 zamontowanej w ciągniku Pronar 5110: $A_{1}=0,80698 ; A_{2}=0,46902 E-4 ; A_{3}=-1,47791 E-8 ; A_{4}=-7,81944 E-4$; $A_{5}=3,80523 E-7\left(R^{2}=99,37 \%\right)$.

Prędkość obrotową sprężarki oblicza się wychodząc z prędkości jazdy, co przy znanym przełożeniu całkowitym układu napędowego ciągnika umożliwia obliczenie prędkości obrotowej silnika a następnie obliczenie prędkości obrotowej sprężarki:

$$
n_{k}(t)=\frac{30 \cdot i_{c} v}{\pi \cdot i_{k} r_{k}(1-s)} \quad[\mathrm{obr} / \mathrm{min}]
$$

gdzie: v - prędkość jazdy [m/s], $\mathrm{i}_{\mathrm{c}}$ - przełożenie całkowite układu napędowego ciągnika, $i_{k}$ - przełożenie napędu sprężarki, $r_{k}$ - promień kinematyczny koła [m], s - poślizg kół napędowych.

Podczas hamowania prędkość obrotowa spada od prędkości odpowiadającej prędkości na początku hamowania do prędkości obrotowej silnika na biegu jałowym:

$$
n_{k}(t)=n_{k h}-a_{1} \cdot t \text { dla } n_{k}>n_{k j}
$$

gdzie: $\mathrm{n}_{\mathrm{kh}}$ - prędkość obrotowa odpowiadająca prędkości jazdy na początku hamowania [obr/min], $a_{1}$ - współczynnik spadku obrotów sprężarki (obrotów silnika) podczas hamowania określony doświadczalnie [obr/(min·s)], $\mathrm{n}_{\mathrm{kj}}$ - prędkość obrotowa wału sprężarki podczas pracy silnika na biegu jałowym [obr/min].

Równanie bilansu masowych strumieni w zbiorniku ma postać:

$$
\frac{d m_{z}}{d t}=\dot{m}_{k}-\dot{m}_{s}-\dot{m}_{c}
$$

gdzie: $\dot{m}_{s}$ - strumień masowy wpływający do magistrali zasilającej $[\mathrm{kg} / \mathrm{s}], \dot{m}_{c}$ - strumień masowy wpływający do magistrali sterującej $[\mathrm{kg} / \mathrm{s}]$.

Wykorzystując zasadę zachowania energii dla układu otwartego oraz równanie Clapeyrona otrzymuje się następujące zależności, opisujące zmianę ciśnienia i temperatury powietrza w zbiorniku [3]: 


$$
\begin{aligned}
& \frac{d p_{z}}{d t}=\frac{1}{V_{z}}\left[(\kappa-1)\left(\dot{Q}+\dot{H}_{k}-\dot{H}_{s}-\dot{H}_{c}\right)\right] \\
& \dot{Q}=\alpha_{z} A_{z}\left(T_{w}-T_{z}\right) \quad \dot{H}_{i}=\dot{m}_{i} c_{p} T_{i} \\
& \frac{d T_{z}}{d t}=\frac{T_{z}}{p_{z} V_{z}}\left[V_{z} \frac{d p_{z}}{d t}-R T_{z}\left(\dot{m}_{k}-\dot{m}_{s}-\dot{m}_{c}\right)\right],
\end{aligned}
$$

gdzie: $\mathrm{H}_{\mathrm{k}}$ - entalpia strumienia ze sprężarki [J], $\mathrm{H}_{\mathrm{s}}$ - entalpia strumienia magistrali zasilającej [J], $\mathrm{H}_{\mathrm{c}}$ - entalpia strumienia magistrali sterującej [J], Q - ciepło wymieniane z otoczeniem [J], $\alpha_{z}-$ współczynnik przejmowania ciepła $\left[\mathrm{W} / \mathrm{m}^{2} \mathrm{~K}\right], \mathrm{T}_{\mathrm{z}}$ - temperatura powietrza w zbiorniku $[K], A_{z}$ - powierzchnia przejmowania ciepła, $T_{w}$ - temperatura ścianek zbiornika $[\mathrm{K}]$.

Temperaturę strumienia dopływającego ze sprężarki można oszacować z równania politropy:

$$
T_{k}=T_{a}\left(\frac{p_{z}}{p_{a}}\right)^{\frac{n-1}{n}}
$$

\section{Przykład zastosowania modelu}

Opisany model matematyczny zespołu zasilającego wykorzystano do budowy w programie Matlab-Simulink modelu komputerowego instalacji pneumatycznej ciągnika Pronar 5110. W zespole sterującym tego ciągnika występuje uruchamiany hydraulicznie zawór 329020 201 firmy Haldex, sterujący hamulcami ciągnika. Pokazany na rys.2 model komputerowy, w wersji przeznaczonej do symulacji funkcjonowania zespołu zasilającego, wykorzystano do sprawdzenia wydatku sprężarki podczas napełniania zbiornika zastępczego o pojemności $60 \mathrm{dm}^{3}$ (imitującego układ hamulcowy przyczepy), podłączonego do złącza zasilającego. Tego typu test stosuje się również podczas badań homologacyjnych ciągników rolniczych [2].

W celu dokonania oceny uzyskanych przebiegów symulacyjnych do modelu komputerowego wprowadzono w postaci komponentu From File (wyróżnionego kolorowym tłem) przebiegi doświadczalne, zarejestrowane podczas badań instalacji pneumatycznej ciągnika.

Przykładowe wyniki badań symulacyjnych w postaci wykresu czasowego ciśnienia $\mathrm{p}_{\mathrm{v}}$ i temperatury $\mathrm{T}_{\mathrm{v}}$ w zbiorniku zastępczym oraz wydajności objętościowej $\mathrm{Q}_{\mathrm{k}}$ sprężarki pokazano na rys.3. W równaniu (11), z którego obliczano temperaturę strumienia powietrza dopływającego ze sprężarki, przyjęto wykładnik politropy $n=1,26$. Na wykresie zamieszczono również przebieg ciśnienia $\mathrm{p}_{\mathrm{ve}} \mathrm{z}$ badań doświadczalnych. Symulacyjne i doświadczalne przebiegi czasowe ciśnienia wykorzystano do walidacji modelu komputerowego. Wyniki obliczonego w programie Matlab testu nieparametrycznego Kołmogorowa-Smirnowa 


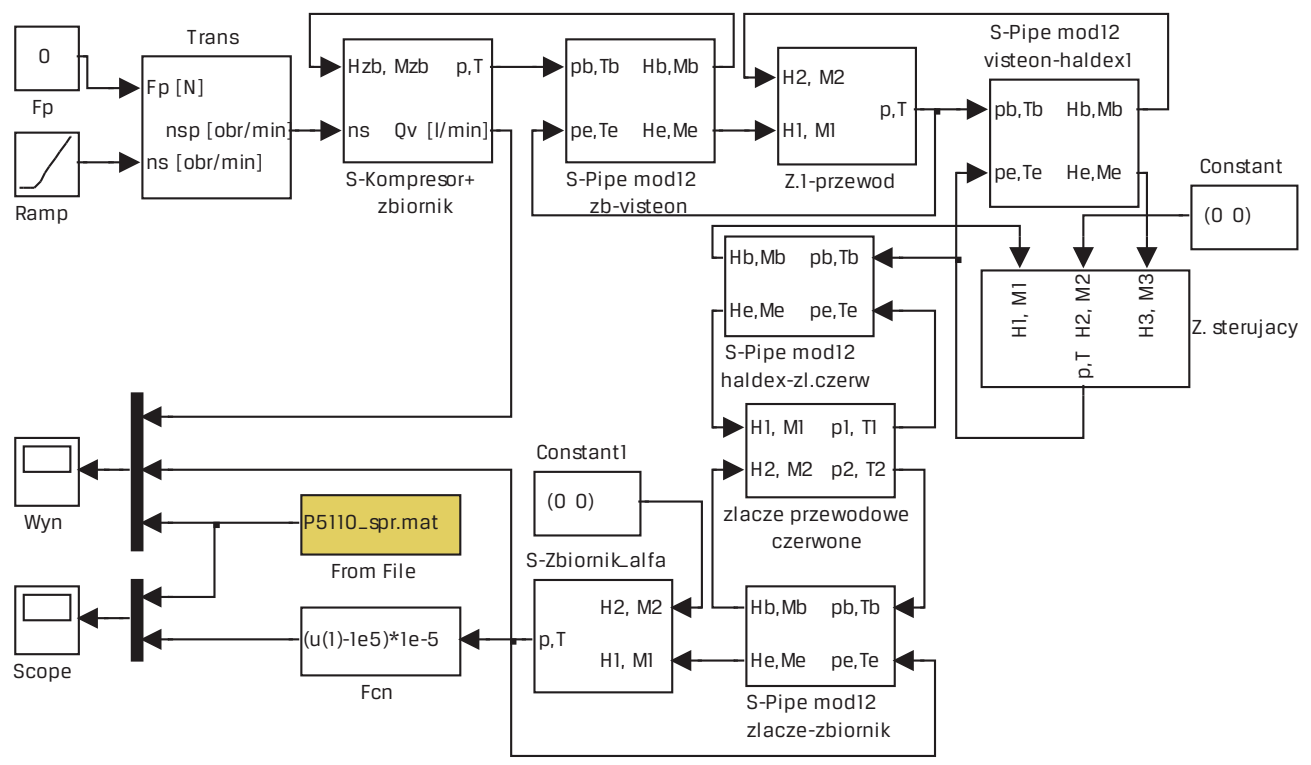

Rys.2. Schemat blokowy instalacji pneumatycznej ciągnika Pronar 5110 do symulacji funkcjonowania zespołu zasilającego (sprężarka 601.23.931 Polmo Praszka).

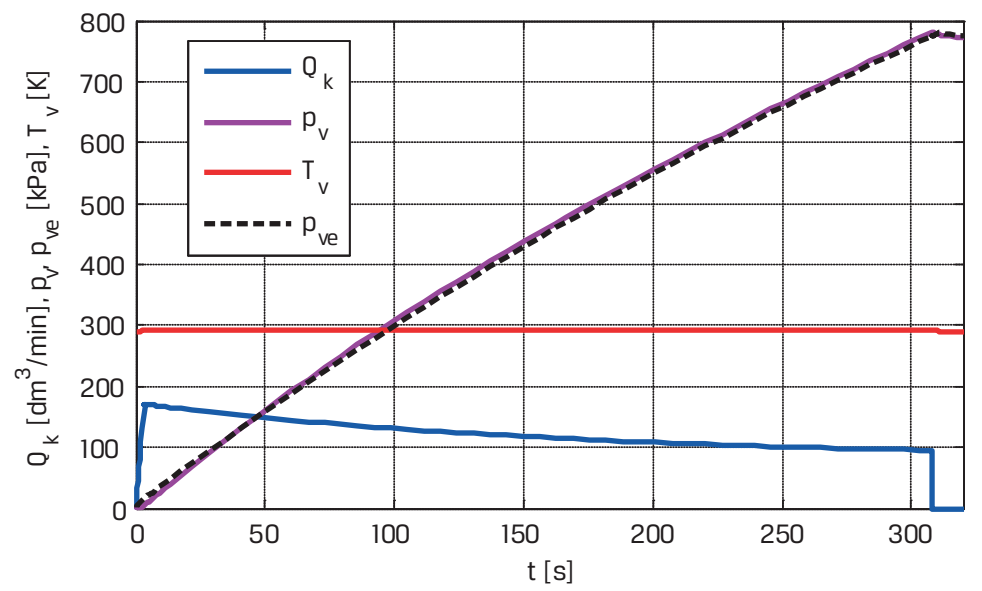

Rys.3. Wyniki symulacji pracy zespołu zasilającego instalacji pneumatycznej ciągnika Pronar 5110 podczas sprawdzania wydatku sprężarki: $Q_{k}$ - wydajność objętościowa, $p_{v}, T_{v}$ - ciśnienie i temperatura, $\mathbf{p}_{\mathrm{ve}}$ - ciśnienie doświadczalne. 
na poziomie istotności 0,05 (ks2=0,0198<0,1923 dla 101 punktów) oraz wartość wskaźnika determinacji $\mathrm{R}^{2}=0.999$ potwierdziły adekwatność modelu komputerowego.

Na podstawie przebiegu modelowego wyznaczono czas osiągania w zbiorniku zastępczym ciśnienia minimalnego 6,5 bar. Czas ten różni się o 2,1s od czasu wyznaczonego doświadczalnie (245,6 s), co również świadczy o zadowalającej dokładności modelu komputerowego z punktu widzenia celu modelowania.

\section{Podsumowanie}

Opracowany model matematyczny zespołu zasilającego może być wykorzystany do budowy modelu komputerowego instalacji pneumatycznej ciągników rolniczych, jak również samochodów użytkowych, w celu prognozowania metodami symulacyjnymi właściwości funkcjonalno-użytkowych instalacji we wczesnym etapie projektowania. Adekwatność zrealizowanego w Matlabie-Simulinku modelu komputerowego zespołu zasilającego została potwierdzona wynikami testu Kołmogorowa-Smirnowa przez porównanie doświadczalnych i symulacyjnych przebiegów czasowych ciśnienia w instalacji podczas sprawdzania poprawności doboru wydatku sprężarki ciągnika rolniczego Pronar 5110.

\section{Literatura}

[1.] BLOCH, H.,P.: A Practical Guide to Compressor Technology. John Wiley \& Sons, Hoboken, New Jersey, 2006.

[2.] KAMIŃSKI Z., CZABAN J.: Propozycja programu badań układów hamulcowych ciągników rolniczych. Motrol. Motoryzacja i energetyka rolnictwa. T.8 (red. Eugeniusz Krasowski). Akademia Nauk Oddział w Lublinie. Komisja Motoryzacji i Energetyki Rolnictwa, 2006. s.92-100.

[3.] KAMIŃSKI Z., KULESZA Z., MIATLUK K., MIATLUK M: Dynamika pneumatycznych układów napędowych (red. F. Siemieniako). Rozprawy naukowe nr 145. Wydawnictwo Politechniki Białostockiej, Białystok 2007.

[4.] MIATLUK M., AVTUŠKO V.: Dinamika pnevmatičeskich i gidravličeskich privodov avtomobilej. Mašinostroenije, Moskva 1980 